\title{
PEMIKIRAN GENDER MENURUT PARA AHLI: Telaah atas Pemikiran Amina Wadud Muhsin, Asghar Ali Engineer, dan Mansour Fakih
}

\author{
Janu Arbain, Nur Azizah, Ika Novita Sari \\ Universitas Islam Negeri (UIN) Walisongo Semarang \\ e-mail: janu.arbain@gmail.com
}

\begin{abstract}
Abstrak
Ajaran agama memiliki potensi dominan dalam penerapan ideologi gender yang bias. Dalam konteks itu pula, agama bisa memberikan inspirasi dan dorongan munculnya ketidakadilan gender. Bagaimana mungkin agama bisa berpotensi menimbulkan ketidakadilan? Tentu saja potensi ketidakadilan itu bukan bersumber dari prinsip agama, melainkan karena proses perkembangan agama yang didominasi oleh budaya patriarkhat. Untuk itu, ajaran agama harus ditinjau kembali dan dianalisis secara krisis, terutama ajaran tentang faktor kodrati atau ilahi dan faktor yang bukan kodrati.Pada dasamya, setiap agama mengajarkan bahwa manusia diciptakan sama derajatnya, baik lakilaki maupun perempuan. ${ }^{1}$ Terdapat beberapa pemikir yang memiliki perhatian besar atas persoalan gender telah mengupas secara teoretis, dan metodologis, diantaranya Amina Wadud Muhsin, Asghar Ali Engineer, dan Mansour Fakih.
\end{abstract}

Kata Kunci: pemikiran gender; Amina Wadud Muhsin; Asghar Ali Engineerr; Mansour Fakih

\section{A. Pendahuluan}

Gender adalah suatu konsep yang digunakan untuk mengidentifikasi perbedaan laki-laki dan perempuan dari sudut non-biologis. Hal ini berbeda dengan sex yang secara umum digunakan untuk mengidentifikasi perbedaan laki-laki dan perempuan dari segi anatomi biologi. Istilah sex lebih banyak berkonsentrasi pada aspek biologis seseorang yang meliputi perbedaan komposisi kimia dan hormon dalam tubuh, anatomi fisik, reproduksi dan karakteristik biologis lainnya. Sementara itu, gender lebih banyak berkonsentrasi pada aspek sosial, budaya, psikologis dan aspek-aspek non-

${ }^{1}$ Nunuk P. Murniati, Getar Gender, (Magelang: Indonesiatera, 2004) h. 3. 
biologis lainnya. Studi gender lebih menekankan perkembangan maskulinitas (masculinity/rujuliyah) atau feminitas (feminity/nisa'iyyah) seseorang. Sedangkan studi sex lebih menekankan perkembangan aspek biologis dan komposisi kimia dalam tubuh laki-laki (maleness/dzukurah) dan perempuan (femaleness/unutsah). Untuk proses pertumbuhan anak kecil menjadi seorang laki-laki atau menjadi seorang perempuan, lebih banyak digunakan istilah gender dari pada istilah seks. Istilah seks umumnya digunakan untuk merujuk kepada persoalan reproduksi dan aktivitas seksual, selebihnya digunakan istilah gender.

Dalam konteks islam persoalan Gender merupakan contoh nyata betapa antara teks kitab suci, penafsiran terhadapnya, dan konteks sosial yang melingkupi sering terjadi benturan -benturan dan ketegangan. Keberagaman ini perlu dikritisi karena sama-sama mengklaim dirinya berpegang pada kitab suci al Qur'an. Isu gender sesungguhnya lahir dari kesadaran kritis kaum perempuan terhadap keterbelakangan kaumnya. Bila kita telusuri sejarah kelam kaum perempuan pada masa lampau khususnya eksistensi atau keberadaan perempuan dimata agama-agama, misalnya saja agama yahudi yang menjauhi perempuan yang haid dan diasingkan ke suatu tempat yang khusus. Demikian juga dengan agama-agama lain seperti agama kristen dan hindu yang selalu menganggap rendah kaum perempuan. Kemunculan gender ini banyak diwarnai ketidakjelasan terutama dalam hal emansipasi perempuan karena kodrat itulah salah satu batasannya yang diusung oleh kementrian agama maupun Negara

\section{B. Amina Wadud}

Amina Wadud Muhsin adalah salah satu pemikir feminis kelahiran Malaysia. Dia menamatkan studinya dari pendidikan dasar hingga perguruan tinggi di Malaysia. Diamenamatkan sarjananya dari Universitas Antar Bangsa, masternya dari University of Michigan Amerika Serikat tahun 1989, dan doktornya dari Harvard University tahun1991-1993. Sekarang ia tinggal di Amerika Serikat menjabat salah satu guru besar di Departemen Filsafat dan Studi Agama pada Universitas Commenwelth di Virginia. Salah satu tulisannya yang kemudian penulis jadikan sebagai bahan kajian terhadap pemikiran feminismenya adalah Qur'an and Woman (1992). Amina pernah membuat geger para ulama dunia, termasuk Syeikh Yusuf al-Qardawi, ketika ia menjadi khathib dan imam shalat Jum'at di 
New York City tanggal 18 Maret 2005. Juga terbit buku Amina yang berjudul Inside the Gender Jihad: Women's Reform in Islam (2006).

Amina Wadud Muhsin adalah seorang perempuan pemikir kontemporer yang dilahirkan di Amerika pada tahun 1952. Ia seorang guru besar pada Universitas Common Wealth di Richmond, Virgina. Wadud mencoba melakukan rekonstruksi metodologis tentang bagaimana menafsirkan al-Qur'an agar dapat menghasilkan sebuah yang sensitif gender dan keadilan. Menurut Charlez Kurzman penelitian Amina Wadud mengenai perempuan dalam al-Qur'an yang tertuang dalam Qur'an and Woman muncul dalam suatu konteks historis yang erat dengan pengalaman dan perkumpulan perempuan Afrika-Amerika dalam upaya menperjuang-kan keadilan gender. Selama ini sistem relasi laki-laki dan perempuan di masyarakat sering mencerminkan adanya bias patriarki sehingga mereka kurang mendapat keadilan secara proposorsional. ${ }^{2}$

\section{Penciptaan Manusia di dalam al-Qur'an (studi gender) menurut Amina Wadud}

Catatan manusia mengenai penciptaan manusia berhubungan dengan tema-tema lainnya yang mencakup seluruh Weltanschauung al-Qur'an: Tauhid, pedoman, tanggung jawab moral individu dan persamaan. Misalnya, fenomena pasangan dalam penciptaan manusia mendukung prinsip utama al-Qur'an yaitu tauhid: Keesaan Allah. Al-Qur'an menyatakan secara eksplisit bahwa 'tidak ada sesuatu pun yang serupa dengan-Nya'. ${ }^{3}$ Secara filosofis, segala sesuatu diciptakan berpasangan dan Dia yang Maha Menciptakan, tidaklah berpasangan. Sang Pencipta hanya Satu.

\section{a. Asal-usul Manusia}

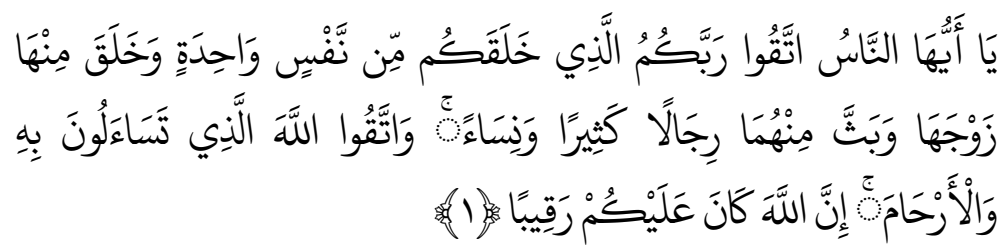
amina.html

${ }^{2} \mathrm{http}: / /$ cikacepet.blogspot.com/2012/03/resume-buku-quran-and-women-karya-

${ }^{3}$ QS. al-Syura: 11 . 
"Hai sekalian manusia, bertakwalah kepadaTuhan-mu yang telah menciptakan kamudahan diri yang satu, dan dari padanya Allah menciptakan istrinya; dan dari pada keduanya Allah memperkembangbiakkan aki-laki dan perempuan yang banyak. Dan bertakwalah kepada Allah yang dengan (mempergunakan) nama-Nya kamu saling meminta satu samalain, dan (peliharalah) hubungan silaturahmi. Sesungguhnya Allah selalu menjaga dan mengawasi kamu." (QS. al-Nisa: 1). ${ }^{4}$

\section{b. Dualisme Penciptaan}

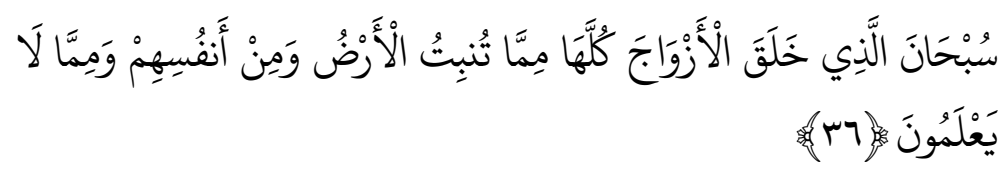

"Maha Suci Tuhan yang telah menciptakan pasangan-pasangan semuanya, baik dari apa yang ditumbuhkan oleh bumi dan dari diri mereka maupun dari apa yang tidak mereka ketahui." (QS, Yasin: $36)^{5}$

Pandangan Qur'ani tentang penciptaan manusia membentuk hubungan khusus antara Sang Pencipta (Allah) dengan makhluk yang diciptakan (manusia). Hubungan itu merupakan landasan bagi keberadaan al-Qur'an dan sebagai pedoman yang menghubungkan dengan penciptaan. Pandangan al-Qur'an mengenai kisah di surga menekankan pentingnya tanggung jawab individual. Nafs menunjukkan individual itu. Oleh sebab itu perbuatan baik apapun yang dilakukan, maka itu adalah untuk dirinya sendiri (Nafs) dan setiap perbuatan buruk yang dilakukan, maka akibatnya juga pada diri sendiri. ${ }^{6}$

\section{Metode Penafsiran al-Qur'an Amina Wadud}

Dalam bukunya Qur'an and Woman, Amina mengawali pembahasannya dengan mengritik penafsiran-penafsiran yang selama ini ada mengenai perempuan dalam Islam. Ia membagi penafsiran tersebut ke dalam tiga kategori, yaitu tradisional, reaktif, dan holistik. Tafsir tradisional, menurut

\footnotetext{
${ }^{4}$ AminaWadud, Wanita di dalam a-Qur'an, (Bandung: Pustaka, 1992), h. 22.

${ }^{5}$ Ibid., h. 28.

${ }^{6}$ Ibid., h. 34-36.
} 
Amina, memberikan interpretasi-interpretasi tertentu sesuai dengan minat dan kemampuan mufassirnya yang bisa bersifat hukum, tasauf, gramatik, retorik, atau historis. Metodologi yang digunakan bersifat atomistik, yaitu penafsiran dilakukan dengan mengupas ayat per ayat secara berurutan. Tidak ada upaya untuk menempatkan dan mengelompokkan ayat-ayat sejenis ke dalam pokok-pokok bahasan yang tertulis. Yang ditekankan oleh Amina bahwa tafsir-tafsir tradisional itu ditulis oleh kaum laki-laki secara eksklusif. Itulah sebabnya maka hanya laki-laki dan pengalaman laki-laki saja yang direkomendasikan dalam tafsir itu. Sedang perempuan -berikut pengalaman, visi, perspektif, keinginan, atau kebutuhannya- ditundukkan pada pandangan laki-laki. ${ }^{7}$

Kategori kedua adalah tafsir yang isinya terutama mengenai reaksi para pemikir modern terhadap sejumlah besar hambatan yang dialami perempuan yang dianggap berasal dari al-Qur'an. Persoalan yang dibahas dan metode yang digunakan seringkali berasal dari gagasan kaum feminis dan rasionalis, namun tanpa dibarengi analisis yang komprehensif terhadap al-Qur'an. Dengan demikian meskipun semangat yang dibawa adalah pembebasan, namun tidak terlihat hubungannya dengan sumber ideologi dan teologi Islam, yaitu al-Qur'an. ${ }^{8}$ Kategori ketiga adalah tafsir yang menggunakan seluruh metode penafsiran dan mengaitkan dengan berbagai persoalansosial, moral, ekonomi, dan politik, termasuk isu tentang perempuan pada era modern ini. Menurut Amina, tafsir model ini merupakan metode terbaik. Dalam kategori inilah Amina menempatkan karyanya. ${ }^{9}$

Metode penafsiran yang digunakan Amina adalah metode yang pernah ditawarkanoleh Fazlur Rahman, yaitu metode neomodernis. Rahman berpendapat bahwa ayat-ayat al-Qur'an yang diturunkan dalam waktu tertentu dalam sejarah - dengan keadaan yang umum dan khusus yang menyertainya - menggunakan ungkapan yang relatif mengenai situasi yang bersangkutan. Oleh karena itu, pesan al-Qur'an tidak bisa dibatasi oleh situasi historis pada saat ia diwahyukan saja. Seorang sahabat yang membaca al-Qur'an harus memahami implikasi-implikasi dari pernyataanpernyataan al-Qur'an pada waktu diwahyukan untuk menentukan makna

7Ibid., h. 1-2.

${ }^{8}$ Ibid., h. 3.

${ }^{9}$ Ibid., h. 3. 
yang dikandungnya. Di sisi lain, generasi Islam selanjutnya, yang situasi dan kondisinya berbeda dengan masa Rasulullah, harus tetap membuat aplikasi praktis dari pernyatan-pernyataan al-Qur'an yang tetap mempertimbang-kan makna utama yang dikandungnya. ${ }^{10}$

Dengan argumen ini, Amina yakin bahwa dalam usaha memelihara relevansinyadengan kehidupan manusia, al-Qur'an harus terus-menerus ditafsirkan ulang. Pembahasan Amina mengenai kedudukan perempuan dalam buku tersebut cukup ringkas dan terkesan simpel. Namun, dalam buku tersebut ia menonjolkan semangat egalitarianisme. Ia tidak menganggap matriarkisme adalah alternatif bagi patriarkisme yang selama ini dituding sebagai penyebab ketersudutan perempuan. Ia menginginkan suatu keadilan dan kerja sama antara kedua jenis kelamin tidak hanya pada tataran makro (negara, masyarakat), tetapi juga sampai ke tingkat mikro (keluarga). ${ }^{11}$

\section{Asghar Ali Engineer}

Asghar Ali Engineer lahir pada tanggal 10 Maret 1939 dalam sebuah keluarga priyayi ortodoks di Bohra. Bohra merupakan daerah yang masyarakat muslimnya menganut aliran Syi'ah Ismailiyah. Ayahnya bernama Sheikh Qurban Husain, ibunya bernama Maryam. Meskipun ia seorang penganut Syi'ah Ismailiyah yang fanatik tapi berpikiran terbuka dan menunjukkan perhatian besar ketika orang-orang yang berbeda keyakinan mengajaknya berdialog. Sejak kecil, Asghar telah terbiasa menyaksikan ayahnya berdialog dengan para pemuka agama lain, menyaksikan mereka saling bertukar pikiran dan juga membela keyakinannya masing-masing.

Melalui ayahnya, Asghar Ali Engineer mempelajari ilmu-ilmu keislaman seperti teologi, tafsir, hadis dan fiqh. Bahkan ia juga pernah menempuh pendidikan formal dari tingkat dasar dan lanjutan pada sekolah yang berbeda-beda, seperti Hoshangabad, Wardha, Dewas dan Indore. Adapun pendidikan tingginya dimulai pada tahun 1956. Enam tahun kemudian, yaitu tahun 1962, ia berhasil menyelesaikannya dan akhirnya memperoleh gelar Doktor dalam bidang teknik sipil dari Vikram University, Ujjain (India). Di samping itu, Asghar Ali Engineer juga menguasai

${ }^{10} \mathrm{Ibid} .$, h. 4.

${ }^{11}$ Marzuki, Perempuan dalam Pandangan Feminis Muslim, h. 8-10, http://staff.uny.a.id. 
berbagai bahasa, seperti Inggris, Arab, Urdu, Persia, Gujarat, Hindi dan Marathi. Dengan menguasai berbagai bahasa tersebut Asghar Ali Engineer mempelajari dan menekuni masalah-masalah agama. Ia mempelajari fiqh perbandingan yang meliputi empat mazhab sunni dan juga mazhab Syi'ah Isma'iliyah. Engineer adalah seorang feminis yang sangat gigih membela hak-hak wanita dalam Islam, Dia mempelajari berbagai mazhab hukum serta berusaha mengambil putusan yang paling baik tentang wanita dari mazhab-mazhab tersebut dengan jalan talfiq. Bahkan dengan serius ia membaca tentang rasionalisme, baik yang berbahasa Urdu, Arab ataupun Inggris. Asghar Ali Engineer juga membaca tulisan-tulisan Niyaz Fatehpuri (seorang penulis berbahasa Urdu yang terkenal dan pengkritik ortodoksi), Bertrand Russel (seorang filosof rasional asal Inggris), dan juga karya monumental Karl Marx, Das Capital.

Di samping sebagai pemikir, Asghar Ali Engineer juga adalah seorang aktifis sekaligus seorang Da'i yang memimpin sekte Syi'ah Isma'iliyah, Daudi Bohras yang berpusat di Bombay India. Untuk diakui sebagai Da'i tidaklah mudah. Ia harus memenuhi 94 kualifikasi yang secara ringkasnya dibagi dalam empat kelompok. Pertama, kualifikasi-kualifikasi pendidikan. Kedua, kualifikasi-kualifikasi administratif. Ketiga, kualifikasi-kualifikasi moral. Keempat, kualifikasi-kualifikasi keluarga dan kepribadian. Bahkan yang lebih menarik lagi, di antara kualifikasi tersebut, seorang Da'i harus tampil sebagai pembela umat yang tertindas dan berjuang melawan kezaliman. Baginya, harus ada keseimbangan antara refleksi dan aksi.

Dengan memahami posisi Asghar Ali Engineer di atas, maka tidaklah mengherankan mangapa ia sangat vokal sekali dalam memperjuangkan dan menyuarakan pembebasan. Suatu tema yang menjadi ruh pada setiap karyanya, seperti hak asasi manusia, hak-hak wanita, pembelaan rakyat tertindas, perdamaian etnis, agama, dan lain-lainnya. Itulah sebabnya, ia banyak terlibat bahkan memimpin organisasi yang memberikan banyak perhatian kepada upaya advokasi sosial. ${ }^{12}$

\section{Penciptaan Manusia}

Maha suci Allah, Maha suci Ia menciptakan manusia dalam rahim seorang wanita. Hal yang tidak mungkin bagi pria. Tetapi, sayang tentang

${ }^{12}$ http://www.referensi-islam-negara.com/2013/01/-asghar-ali-engineer.html 
yang demikian disangkal oleh sebagian umatNya. Sedemikian rupa mereka mengingkari kodrat Allah sesuai firman-Nya, yang tertera dalam surat alNisa 4:1 dan surat al-Hujurat 49:13. Perempuan seperti disinggung di muka, sangat tidak berdaya di dunia Arab dan di seluruh dunia. Namun demikian, Rasulullah dengan al-Qur'an (surat al-Baqarah: 228) mendeklarasikan hakhak perempuan, yang sebelumnya tidak pernah mereka dapatkan dalam aturan yang legal.

Pada saat al-Qur'an turun itulah untuk pertama kalinya keberadaan individu perempuan sebagal makhluk khidup diterima tanpa ada persyaratan. Perempuan dapat melangsungkan pernikahan, dapat meminta cerai kepada suaminya tanpa persyaratan diskriminatif, dapat mewarisi harta ayah, ibu, dan saudaranya yang lain, dapat memiliki harta sendiri dengan hak penuh, dapat merawat anak-anaknya hingga dewasa, dan dapat mengambil keputusan sendiri secara bebas. Di Eropa, perempuan tidak berhak memiliki harta hingga akhir abad ke-19 sedangkan di Amerika, perempuan baru mempunyai hak pilih pada sekitar tahun 1920 .

Kalau perempuan dikatakan menderita karena suaminya boleh menikah lebih dan satu wanita (sampai empat), itu hanya sebuah stigma. Tidak dapat disangkal bahwa stigma itu memang merendahkan status perempuan, yang sesungguhnya sederajat dengan laki-laki. Tetapi laki-laki Arab mempunyai kebiasaan menikah dengan banyak istri dan Islam datang membatasi hanya sampai empat. Pemikahan lebih dan satu kali diizinkan dengan aturan yang ketat, yaitu untuk melindungi janda-janda dan anakanak yatim serta harta mereka; sehingga bukan untuk kesenangan laki-laki semata. Tetapi jika laki-laki kuatir tidak dapat berlaku adil, maka kawinlah satu orang saja. Demikian pesan inti surat al-Nisa': 3. Biarlah stigma yang berlaku saat ini terkubur dalam sejarah seiring dengan semakin meningkatkan kesadaran dan kecerdasan kaum perempuan. Ketidak-berdayaan perempuan ini seharusnya juga dilihat dalam konteks sosiologis. Jika masyarakat atau konteks berubah, maka ketidak-berdadayaan ini harus ikut berubah. Prinsip dasar kebebasan dan harkat individu perempuan (seperti isyarat al-Qur'an) adalah lebih daripada ketidak-berdayaan secara sosiologis. ${ }^{13}$

13Bismar Siregar, Islam dan Hukum, (Jakarta: Grafikatama Jaya, 1992), h. 217. 


\section{Metodologi Pemikiran Asghar Ali Engineer}

\section{a. Tentang Poligami}

Beberapa ayat al-Qur'an merupakan ayat yang berwajah ganda. Misalnya saja ayat tentang poligami dan kepemimpinan perempuan. Poligami dianggap diperbolehkan, sementara yang lain mengatakan itu sebagai dalil monogami berdasarkan QS. al-Nisa': 3. Demikian juga ayat tentang kepemimpinan perempuan.

Perwajahan ganda ini muncul akibat pembacaan yang tidak fair terhadap ayat-ayat al-Qur'an. Yakni, mengambil pesan sebuah ayat sembari mengabaikan spirit yang mendasari ayat itu turun. Ali kemudian menyodorkan sebuah metodologi demi mengatasi hal ini. Ali mengajukan dua konsep: ayat normatif dan ayat kontekstual. Ayat normatif, bersifat das solen, "yang seharusnya". Ia merupakan ayat-ayat yang mengungkapkan pernyataan normatif atau mengandung nilai universal sehingga berlaku sepanjang masa. Sementara ayat kontekstual adalah ayat-ayat yang mengungkapkan pernyataan kontekstual atau berkait dengan keadaan masyarakat ketika itu. Ia bersifat das sein, 'yang senyatanya'.

Tujuan pembedaan antara ayat normatif dan ayat kontekstual adalah untuk mengetahui perbedaan antara yang sebenarnya diinginkan oleh Allah dan yang dibentuk oleh realitas masyarakat pada waktu itu. Keduanya merupakan kekayaan al-Qur'an. Sebab Kitab Suci ini tidak hanya berbicara tentang masyarakat ideal, tetapi juga mempertimbangkan realitas empiris.

Ayat-ayat berwajah dua di atas dikategorikan oleh Ali sebagai ayat konstekstual. Ia berlaku sesuai konteks ketika ayat itu diturunkan. Poligami diperbolehkan pada zaman Nabi sebab ia diyakini jalan yang ampuh untuk mengangkat martabat perempuan yang terpuruk saat itu. Kini zaman sudah berubah. Perempuan sudah (lumayan) baik posisinya di masyarakat. Poligami menjadi sebuah anjuran atas nama memuliakan perempuan? Tidak, kata Ali. Ayat tentang penciptaan manusia, laki-laki dan perempuan, dari esensi yang sama (QS. al-Nisa': 1), pemuliaan semua anak Adam (QS. al-Isra': 70), dan pemberian pahala yang sama bagi yang bertakwa, baik lakilaki ataupun perempuan (QS. al-Ahzab: 35) merupakan contoh ayat normatif. Ali juga menegaskan bahwa sesungguhnya al-Qur'an menghendaki kesetaraan antara laki-laki dan perempuan, tapi konteks sosial ketika itu 
tidak dapat menerima hal demikian. Jika dipaksakan, maka dakwah Nabi akan mengalami kesulitan besar. ${ }^{14}$

\section{b. Tentang Kepemimpinan Wanita}

Fenomena diskriminasi terhadap perempuan di dunia Muslim merupakan implikasi langsung dari pemahaman teks-teks skriptural. Diskriminasi gender bukan semata-mata persoalan sosiologis, namun telah menjadi bagian dari persoalan teologis. Perempuan sebagai posisi kelas dua dibawah laki-laki, baik pada dataran domestik maupun publik, merupakan implikasi logis dari interpretasi terhadap sumber-sumber teologi Islam. Hadis-hadis patriarkal dianggap sebagai fundamental idea munculnya dominasi laki-laki terhadap perempuan. Hadis ini terdapat dalam kitab Sahih Bukhari. Sebagai i'itibar hadis, diriwayatkan pula dalam Sunan atTurmuzi dan Sunan an-Nasa'i.

Hadis ini dipegangi oleh kaum tradisionalis sebagai argumen untuk melarang perempuan berkiprah di dunia politik dan publik. Secara tekstual hadis ini memang menginyaratkan pelarangan Rasulullah terhadap kepemimpinan perempuan. Namun, pendekatan tekstual untuk memahami hadis ini bukan merupakan pembacaan yang objektif. Pada gilirannya, ideal moral hadis tidak disampaikan dan secara praktis merugikan hak-hak kemanuisaan perempuan apalagi ditambah dengan Ayat Suci al-Qur'an surat An-Nisa ayat 34. Untuk memahami hadis itu, diperlukan pemahaan historis dan kontekstual. Hadis diatas tadi memang dikategorikan hadis shahih tetapi mempunya latarbelakang sejarah tersendiri (sabab wurud) sehingga tidak bisa serta merta langsung digunakan sebagai dalil umum. Pada dasarnya, sukses atau tidaknya kepemimpinan perempuan, bukanlah karena kemampuan perempuan 'separo' laki-laki, melainkan tergantung penerimaan mayoritas laki-laki dalam kepemimpinannya itu.

Fakta sejarah membuktikan bahwa di Indonesia masa lalu, perempuan Indonesia juga berkesempatan dan berpeluang memegang jabatan kekuasaan sebagai kepala negara, dan berperan aktif dalam berbagai aspek sosial kemasyarakatan, baik sosial, ekonomi, sosial budaya, maupun politik. Bahkan memanggul senjata dalam bidang militer tanpa harus meninggalkan

\footnotetext{
${ }^{14}$.http://wahidinstitute.org/Jaringan/Detail/?id=4/hl=id/Asghar_Ali_Engineer_Alquran _Untuk_Perempuan_Dan_Kaum_Tertindas
} 
perannya di ruang domestik. Dari fakta-fakta sejarah, dapat disimpulkan bahwa dasarnya perempuan dan laki-laki adalah sama. Yaitu sama-sama memiliki potensi dan kecerdasan, keinginan, dan cita-cita, impian, dan harapan, juga rasa khawatir, dan kecemasan. Dengan kecerdasan ilmu pengetahuan yang diperoleh perempuan, dia tidak hanya mampu berperan sebagai ibu dari anak-anak atau istri yang hanya berkutat di ranah domestik. Akan tetapi, mereka juga mempunyai potensi dan dituntut untuk terus dikembangkan. Kepemimpinan sendiri berarti memperoleh atau mencapai keunggulan sebagai individu dalam masyarakat atau wilayah yang disebut publik. Kepemimpinan bisa juga berarti kompetensi dan hirarki, dan juga berkaitan dengan masalah kekuasaan dan tanggung jawab. Jadi, kepemimpinan yang baik adalah yang punya kemampuan untuk mengambil keputusan dengan adil dan bijaksana, tanpa memandang jenis kelamin, entah itu laki-laku ataupun perempuan..$^{15}$

\section{c. Hak Perempuan dan Anak}

Ada saja yang merasa aneh dan ganjil membicarakan perlindungan wanita dan anak. Namun, tentu saja ada yang merasa tersinggung, seakan merendahkan derajat wanita. Sebab, bila wanita dilindungi tentulah pria yang menjadi pelindung. Jangan emosi dengan menuding pria tidak tahu diri walaupun emosi termasuk rahmat Tuhan. Yang tidak dibenarkan adalah emosi yang meluap sehingga hilang pertimbangan akal. Bila demikian, emosi meluap sama dengan binatang. Bahkan lebih rendah derajatnya dibanding binatang. Ada hikmah Tuhan menciptakan manusia berpasang-pasangan, tidak sama badaniah dan batiniah antara pria dan wanita. Oleh sebab itu, jangan ada yang memintari apalagi menuntut persamaan harkat dan kedudukan ala kaca mata manusia. Jadi sudah menjadi hal yang wajib kita syukuri agar peranan wanita dan pria bermanfaat bagi pembinaan anak dalam rangka berbangsa dan bernegara.

Ikatan lahiriah, memahami tanggungjawab suami melindungi istri. Ikatan batiniah bernafaskan cinta, kasih dan sayang atas dasar membentuk keluarga. Keluarga dimaksud tidak memadai bila hanya antara suami dan istri tanpa kehadiran anak. Perlindungan wanita dan anak dalam kehidupan

${ }^{15} \mathrm{http} / /$ sapsepshop.blogspot.com/2011/12/benarkah-islam-melarang-perempuan. html 
rumah tangga, tersirat dalam undang-undang yang merumuskan makna perkawinan, antara lain adanya ikatan lahir dan batin. ${ }^{16}$

\section{Mansour Fakih}

Mansour Fakih lahir di desa Ngawi, Bojonegoro, Jawa Timur, 10 Oktober 1953. Dia merupakan anak pertama di antara sembilan bersaudara yang semuanya adalah laki-laki dari pasangan Mansur bin Yahya dan Siti Maryam binti Imam Fakih. Mansour Fakih menikah dengan Nena Lam'anah dan dikaruniai dua putra, Farabi Fakih, dan Fariz Fakih. Kehidupan Mansour Fakih tergolong sederhana.Tapi, komitmennya terhadap pemberdayaan jangan diremehkan.Bahkan, penyuka film The Burning Season dan Apocalypse Now tersebut sangat tidak setuju menggunakan istilah "penyandang cacat" atau tidak mampu. Dia betah menggunakan diffable, singkatan dari different ability. Dia selalu bersemangat membahas diffable sebagai bagian integral dari keseluruhan hak-hak asasi manusia. Mansour Fakih banyak terlibat dalam organisasi kelompok-kelompok marginal. Hidup dan perjalanan intelektualnya yang sarat dengan pergolakan pemikiran menentang ketidakadilan serta gerakan sosial menjadikan pribadi Mansour dikenal khalayak luas.

Karir Mansour Fakih dimulai ketika dia lulus sebagai sarjana dari Fakultas Ushuluddin IAIN Syarif Hidayatullah, Jakarta, awal 1970-an. Ketika teman-temannya berkiprah di arena politik, dia memilih memusatkan pemikirannya pada proses-proses pendidikan dan mulai menggumuli rasionalisme Islam, dan aktif di Lembaga Penelitian, Pendidikan, dan Pengembangan Ekonomi dan Sosial. Karir pendidikannya diteruskan pada tahun 1990. Mansour Fakih meraih master of education dari University of Massachussetts dalam bidang pendidikan dan perubahan sosial. Karena kemampuannya yang tinggi, almamater dia di Amherst memberikan kesempatan bagi dirinya untuk meraih gelar doktor pada 1994. Kiprah Mansour Fakih tercatat di Lembaga Studi Pembangunan (LSP). Pengalamannya bertemu kalangan intelektual yang memperkuat pemikiran kritisnya kemudian memicu dirinya untuk mendirikan Perhimpunan Pengembangan Pesantren dan Masyarakat serta turut menyimak sekolah akar rumput Institut Pengembangan Masyarakat.

16Bismar Siregar, Islam dan Hukum, h. 204. 
Mansour Fakih sempat terlibat mengembangkan kelompok pendidikan non-formal di Pusat Pelatihan Pendidikan Masyarakat, Jayagiri, Lembang. Dia bekerja bersama dua aktivis dari Volunteers in Asia (VIA), yakni Russ Dilts dan Craig Thorburn. Bekerja sama dengan Direktorat Pendidikan Luar Sekolah Depdikbud, kelompok itu turut mengembangkan metodologi pelatihan partisipatif. Di Cirebon, dia juga sempat menularkan pengetahuannya kepada para pengurus Gabungan Koperasi Batik Indonesia (GKBI) pada 1983. Bersama kawan-kawannya, Mansour Fakih mendirikan Institute for Social Transformation (Insist) pada 1997 di Yogyakarta. Sebelumnya, pada 1994, dia terlibat mendirikan Resource Management \& Development Consultants di Jakarta.Terakhir, Mansour tercatat sebagai anggota Komnas HAM. Sebelumnya, dia terpilih sebagai anggota "Helsinki Process", suatu forum internasional yang diprakarsai Kementerian Luar Negeri Finlandia, beberapa negara Selatan, dan LSM internasional. Di samping itu, Mansour Fakih juga pernah menjabat sebagai Country Representative OXFAMGB di Indonesia. Juga keaktifan lain sebagai fasilitator penelitian, pengarah penelitian di ReaD, redaktur jurnal Wacana, menyunting dan menulis buku terbitan Insist press dan Pustaka Pelajar Yogyakarta.

Pemikiran Mansour Fakih seakan mewakili pemikiran Karl Marx. Namun pemikiran yang banyak diintrodusir oleh Mansour sendiri lebih condong pada gagasan Antonio Gramsci pengikut Marxisme yang terkenal dengan gagasan hegemoni sebagai kritik atas aliran Marxisme tradisional. Kemudian juga dipengaruhi oleh Paulo Freire penggagas pendidikan kaum tertindas, serta Michel Foucoult salah seorang tokoh Posmodernisme yang mengupas relasi kekuasaan dan pengetahuan. Jurgen Habermas salah seorang penganut Kritisisme Mazhab Frankfurt. Mansour Fakih termasuk sosok pemikir yang produktif. Banyak ide-ide yang dia miliki telah diterbitkan menjadi sebuah buku.Karya-karyanya terinspirasi oleh aktivitasnya yang intens bergaul, diskusi dengan berbagai kalangan dan khususnya kaum-kaum marginal.Kegiatan pendampingan yang dia lakukan seperti pendidikan kerakyatan dan sebagainya memberikan penjelasan yang utuh mengenai persoalan kemiskinan, bias gender dan tentang ketidakadilan pendidikan. Tulisan Mansour sangat mengalir dalam menjelaskan pemikirannya dan mudah dimengerti. Teori-teori perubahan sosial yang banyak dia geluti dan pendampinganpendampingan yang dia lakukan 
seperti menjadi fasilitator program pendidikan kerakyatan banyak memberikan masukan terhadap bingkai teori sosial yang sudah ada khususnya di Indonesia. Dan sebagaimana perjalanan intelektualnya yang sering bersinggungan dengan pemikiran-pemikiran kiri, menjadikan karya-karyanya terasa keras tetapi realistis.

\section{Karya-karya Mansour Fakih}

Beberapa karya Mansour Fakih pertama, Masyarakat Sipil Untuk Transformasi Sosial; Pergolakan Ideologi LSM di Indonesia, Kedua, Analisis Gender dan Transformasi Sosial, Ketiga, Runtuhnya Teori Pembangunan Dan Globalisasi, Keempat, Jalan Lain: Manifesto Intelektual Organik. Banyak juga tulisan Mansour yang tersebar dalam pengantar sebuah buku seperti dalam Ideologi-ideologi Pendidikankarya William F. Oneill dengan judul 'Ideologi dalam Pendidikan'. Ada juga tulisannya yang berjudul 'Komodifikasi Pendidikan Sebagai Ancaman Kemanusiaan' menjadi pengantar buku Francis Wahono (Kapitalisme Pendidikan Antara Kompetisi dan Keadilan). Mansour Fakih wafat di RS Bethesda Yogyakarta pukul 23.55 pada Minggu 2004, setelah sebelumnya dirawat intensif 10 hari. Sebelum menjalani perawatan, ia pernah terkena stroke pada 1998 itupun masih tampak sehat, bahkan mengemudikan mobil menuju rumah sakit. Namun, beberapa saat kemudian, aktivis sosial tersebut langsung koma dan tidak pernah sadar hingga meninggal. ${ }^{17}$ Konsep penting yang perlu dipahami dalam rangka membahas masalah kaum perempuan adalah membedakan antara konsep seks (jenis kelamin) dan konsep gender.Pemahaman dan pembedaan terhadap kedua konsep tersebut sangat diperlukan karena alasan dari kedua konsep.

Kepentingan itu muncul untuk mengangkat persoalan-persoalan ketidakadilan sosial khususnya yang menimpa perempuan.Hal ini disebabkan karena ada kaitan yang erat antara perbedaan gender (gender differentces) dan ketidakadilan gender (gender inequalities) dengan struktur ketidakadilan masyarakat secara lebih luas. Dengan pemahaman dan pembedaan yang jelas antara konsep seks dan gender sangat diperlukan dalam membahas ketidakadilan sosial. 2001)

${ }^{17}$ Mansour Fakih, Pendidikan Popular, Membangun Kesadaran Kritis, (Yogyakarta: Insist, 
Perbedaan gender (gender differences) pada proses berikutnya melahirkan peran gender (gender role) dan dianggap tidak menimbulkan masalah, maka tak pernah digugat. Jadi secara biologis (kodrat) kaum perempuan dengan organ reproduksinya bisa hamil, melahirkan, menyusui dan kemudian mempunyai peran gender sebagai perawat, pengasuh dan pendidik, sesungguhnya tidak ada masalah dan tidak perlu di gugat. Akan tetapi yang menjadi masalah dan perlu di gugat oleh mereka yang menggunakan analisis gender adalah struktur "ketidakadilan" yang ditimbulkan oleh peran gender dan perbedaan tersebut. Dari studi yang dilakukan dengan menggunakan analisis gender ini ternyata banyak ditemukan pelbagai manifestasi ketidakadilan seperti dalam uraian berikut:

a. Marginalisasi (pemiskinan ekonomi) terhadap kaum perempuan. Meskipun tidak setiap marginalisasi perempuan disebabkan oleh ketidakadilan gender, namun yang dipersoalkan dalam analisis gender adalah marginalisasi yang disebabkan oleh perbedaan gender. Misalnya, banyak perempuan desa tersingkirkan dan menjadi miskin akibat program pertanian yang hanya di fokuskan kepada kaum laki-laki. Hal ini karena asumsinya bahwa petani itu identik dengan petani laki-laki.

b. Subordinasi pada salah satu jenis kelamin, umumnya kepada kaum perempuan. Dalam rumah tangga, masyarakat, banyak kebijakan dibuat tanpa menganggap penting kaum perempuan. Misalnya, perempuan hanya pantas di dapur atau hanya sebatas konco wingking.

c. Stereotype (pelabelan negatif) terhadap jenis kelamin tertentu dan akibat dari stereotype itu terjadi terjadi diskriminasi serta berbagai ketidakadilan lainnya. Dalam masyarakat banyak sekali pelabelan negative yang diletakkan kepada kaum perempuan yang berakibat membatasi, menyulitkan, memiskinkan dan merugikan kaum perempuan. Karena adanya keyakinan masyarakat bahwa laki-laki adalah pencari nafkah utama. Tapi jika perempuan bekerja itu hanya dinilai sebagai tambahan dan dibayar lebih rendah.

d. Violence (kekerasan) terhadap jenis kelamin tertentu, umumnya perempuan, karena perbedaan gender. Kekerasan ini mencakup kekerasan fisik seperti pemerkosaan dan pemukulan, sampai kekerasan secara halus seperti pelecehan. Banyak sekali kekerasan yang dilakukan terhadap perempuan yang diakibatkan karena adanya stereotype gender. 
e. Burden (beban ganda), adanya anggapan bahwa kaum perempuan memiliki sifat memelihara dan rajin, serta tidak cocok untuk menjadi kepala rumah tangga, berakibat bahwa semua pekerjaan domestic rumah tangga menjadi tanggung jawab kaum perempuan. Misalnya, di kalangan keluarga miskin beban yang sangat berat ini harus ditanggung oleh perempuan sendiri. Terlebih-lebih jika si perempuan terus bekerja, maka ia memikul beban kerja ganda.

Semua manifestasi ketidakadilan gender tersebut saling terkait dan saling mempengaruhi. Manifestasi ketidakadilan itu tersosialisasi kepada kaum laki-laki dan perempuan secara mantap, yang lambat laun akhirnya baik laki-laki maupun perempuan menjadi terbiasa dan akhirnya dipercaya bahwa peran gender itu seolah-olah merupakan kodrat. Lambat laun terciptalah suatu struktur dan system keadilan gender yang bisa diterima oleh masyarakat. ${ }^{18}$ Menurut Mansour Fakih, ketidakadilan gender harus dihentikan dengan dua cara, diantaranya ialah:

a. Jangka Pendek, dapat dilakukan upaya-upaya program aksi yang melibatkan perempuan agar mereka mampu membatasi masalahnya sendiri.Misalnya dalam hal mengatasi marginalisasi perempuan di pelbagai objek peningkatan pendapatan, perlu melibatkan perempuan dalam program pengembangan masyarakat serta berbagai kegiatan yang memungkinkan kaum peempuan bisa mendapatkan akses dalam mendapatkan penghasilan tambahan. Akan halnya dalam subordinasi perempuan, perlu diupayakan pelaksanaan pendidikan dan mengaktifkan berbagai organisasi atau kelompok. Untuk menghetikan maslah kekerasan, pelecehan dan stereotype kaum perempuan. Kaum perempuan sendiri harus mulai memberikan pesan penolakan secara tegas kepada mereka yang melakukan kekerasan dan pelecehan agar tindakan tersebut bisa terhentikan.

b. Jangka Panjang. Strategis jangka panjang perlu dilakukan untuk memperkokoh usaha praktis jangka pendek.Misalnya dengan melancarkan kampanye kesadaran kritis dan pendidikan umum masyarakat untuk menghentikan ketidakadilan gender. Upaya strategis itu perlu dilakukan dengan beberapa pendukung seperti melakukan studi tentang

${ }^{18}$ Mansour Faqih, Analisis Gender E Transformasi Sosial, (Yogyakarta: Pustaka Pelajar, 2010) h. 72-77. 
ketidakadilan gender dan manifestasinya baik di masyarakat, Negara maupun dalam rumah tangga. ${ }^{19}$

\section{Pemikiran Mansour Fakih tentang Sistem Pembangunan di Indonesia}

Dalam bagian ini difokuskan terhadap analisis kritis tentang bagaimana ketidakadilan gender dan ketidakpekaan masalah gender telah mempengaruhi pelbagai ideologi besar seperti teori-teori ilmi sosial tentang pembangunan. Istilah pembangunan dipakai dalam bermacam-macam konteks dan seringkali dipergunakan dalam konotasi politik dan ideologi tertentu. Ada banyak kata yang memiliki makna sama dengan kata pembangunan, seperti perubahan sosial, pertumbuhan, kemajuan dan modernisasi. Kata pembangunan sangat tergantung pada konteks siapa yang menggunakan dan dalam kepentingan apa. Maka, pengertian pembangunan ini akan lebih jelas jika dilihat dari konteks grand theoryyang menjadi landasan pelbagai teori mengenai perubahan sosial. Untuk memulainya, ada beberapa ragam sketsa dan perkembangan pelbagai teori ilmu sosial yang berpengaruh terhadap teori-teori pembangunan. Selanjutnya uraian secara kritis difokuskan kepada diskursus pembangunan dan tentang bagaimana ketidakmampuan merubah posisi ideologis kaum perempuan di masyarakat dan kemudian dilanjutkan dengan program Women in Developement. Ada beberapa sketsa teori pembangunan, di antaranya ialah:

a. Teori Evalusi. Zaman pencerahan memberi dampak besar terhadap pemikiran tentang perubahan sosial. Dampak yang paling menonjol adalah munculnya apa yang dikenal sebagai teori evolusi. Teori ini didasarkan pada asumsi tentang perubahan, yaitu bahwa perubahan dilihat segi Natural, Direksional, Imanen, kontinyu bdan sebagai suatu keharusan, Berjalan melalui sebab universal yang sama.

b. Teori Modernisasi. Dalam teori ini, ada skala modernitas yang menganggap sosialisasi harus ada dalam keluarga, sekolahan dan publik yang memegang peran penting dalam perubahan sikap. Oleh karena itu, nilai tradisionalisme memiliki dampak penting terhadap proses perubahan sikap dan disangka sebagai penghambat kaum modernitas

${ }^{19}$ Mansour Fakih, Pendidikan Popular, Membangun Kesadaran Kritis, h. 154-157. 
dalam membawa perubahan ekonomi. Teori Sumber Daya Manusia. Jika teori modernisasi memusatkan perhatian kepada sikap dan nilainilai individu, maka para ekonomi ini lebih menekankan kepada kemampuan produktif sumber daya manusia sebagai modak investasi bagi proses pembangunan dan perubahan sosial.

c. Teori Ketergantungan. Teori ketergantungan lebih menekankan hubungan-hubungan dalam masyarakat, misalnya dalam masalah struktur sosial, kultural, ekonomi dan politik. Asumsi dasar dalam teori ini adalah bahwa keterbelakangan dan pembangunan merupakan konsep yang saling berkaitan. Kata ketergantungan dipakai untuk memberi tekanan kepada kemajuan masyarakat dan ketertinggalan masyarakat pinggiran.

d. Teori Pembebasan. Teori pembebasn ini memberikan titik perhatian alternatif terhadap keterbelakangan dan bagaimana mengatasinya. Teori ini lebih memilih pendekatan secara humanistik ketimbang pendekatan struktural. Asumsi teori ini, menganggap bahwa masyarakat yang berada dalam keadaan terbelakang karena tertindas oleh pemegang kekuasaan dalam masyarakat mereka sendiri. Maka dari ini berasumsi untung mendekati masyarakat secara personal agar dapat maju dan tidak tertindas oleh para penguasa.

Menurut Fakih, teori-teori pembangunan yang berkembang sebenarnya adalah kelanjutan dari proses kolonialisme yang terpental akibat gemuruh tuntutan berbagai pihak. Developmentalisme dilontarkan guna membendung arus sosialisme, sehingga sebenarnya ia tidak lain adalah kemasan baru kapitalisme. Dalam praktiknya, pembangunan memang terlalu sering diartikan semata-mata sebagai pertumbuhan ekonomi, dan abai terhadap masalah keadilan, pemerataan, atau perlakuan manusiawi terhadap berbagai khazanah kebudayaan lokal. Segala sesuatu dilihat sematamata dari perspektif material, termasuk pula manusia. Karena itu, tidak heran bila atas nama pembangunan penggusuran dilegalkan, atas nama stabilitas pembangunan darah rakyat dihalalkan, dan atas nama pembangunan rakyatdalam kabut kebodohan.

\section{E. Kesimpulan}

Amina Wadud adalah seorang tokoh studi islam yang bersikap objektif dalam mengkaji Islam misalnya dalam menafsirkan al-Qur'an seperti yang dapat kita lihat dalam bukunya Qur'an and Women (Wanita di dalam al- 
Qur'an). Engineer ayat-ayat normative aplikasinya lebih bersifat abadi dan fundamental daripada ayat-ayat kontekstual. Konsekuensi dari normativitas yang ada dalam ayat-ayat al-Qur'an ini adalah validitasnya yang transenden. Namun begitu, teologi al-Qur'an tidaklah dogmatis atau mengabaikan realitas empiris yang cenderung dinamis. Engineer juga mengingatkan bahwa seseorang harus berhati-hati dalam menyortir yang kontekstual dari yang normative, baik yang ada dalam al-Qur'an maupun hadist. pemahaman dan pembedaan yang jelas antara konsep seks dan gender sangat diperlukan dalam membahas ketidakadilan sosial. Terbentuknya perbedaan-perbedaan gender dikarenakan oleh banyak hal, diantaranya: dibentuk, disosialisasi-kan, diperkuat bahkan dikontruksi secara sosial kultural melalui ajaran keagamaan maupun negara. Perbedaan gender sesungguhnya tidak menjadi masalah sepanjang tidak melahirkan ketidakadilan gender. Ketidakadilan gender merupakan sistem dan struktur dimana baik laki-laki maupun perempuan menjadi korban dari sistem tersebut.[]

\section{Daftar Pustaka}

Fakih, Mansour, Analisis Gender \& Transformasi Sosial, Yogyakarta: Pustaka Pelajar, 2010.

http://cikacepet.blogspot.com/2012/03/resume-buku-quran-and-women-karyaamina.html

http://definisi-pengertian.blogspot.com/2010/05/pengertian-gender.html di akses tanggal 7 mei

http://sapsepshop.blogspot.com/2011/12/benarkah-islam-melarangperempuan.html

http://wahidinstitute.org/Jaringan/Detail/?id=4/hl=id/Asghar_Ali_Engineer_a 1-Qur'an_Untuk_Perempuan_Dan_Kaum_Tertindas

http://www.referensi-islam-negara.com/2013/01/-asghar-ali-engineer.html

Marzuki, Perempuan dalam Pandangan Feminis Muslim, http://staff.uny.a.id.

Murniati, Nunuk P., Getar Gender. Magelang: Indonesiatera, 2004.

Siregar, Bismar, Islam dan Hukum. Jakarta: Grafikatama Jaya, 1992.

Wadud, Amina, Wanita di dalam al-Qur'an. Bandung: Pustaka, 1992. 
